\title{
KAJIAN WAKTU HIDUP DAN PERGERAKAN AWAN KONVEKTIF BERBASIS CITRA RADAR DAN MODEL ECMWF
}

\author{
Mochammad Donny Anggoro $^{1^{*}, \text { Bagus Pramujo }^{2}}$ \\ ${ }^{\text {I} S e k o l a h ~ T i n g g i ~ M e t e o r o l o g i ~ K l i m a t o l o g i ~ d a n ~ G e o f i s i k a, ~ J a k a r t a ~}$ \\ ${ }^{2}$ Badan Meteorologi Klimatologi dan Geofisika, Jakarta \\ Email : donny.bmkg@gmail.com
}

\begin{abstract}
ABSTRAK
Awan sebagai aktor dalam dinamika atmosfer, penting untuk dipahami terutama awan konvektif. Data radar digunakan untuk menunjukkan karakteristik awan konvektif yang menghasilkan hujan es dan hujan lebat dengan metode digitasi dan metode life history. Nilai VIL maksimum dari studi kasus hujan es di Bogor adalah $45 \mathrm{~kg} / \mathrm{m}^{2}$, reflektivitas maksimum sebesar $65 \mathrm{dBz}$ mencapai ketinggian $9 \mathrm{~km}$ pada jam $15.12 \mathrm{WIB}$. Three Body Scatter Spike (TBSS) muncul sebagai penanda akan terjadinya proses hujan es. Pertumbuhan awan konvektif yang menghasilkan hujan es 5 Juli 2016 di Bogor terjadi selama 140 menit. Tahap cumulus terjadi selama 33 menit, tahap matang terjadi selama 80 menit, dan tahap dissipasi terjadi selama 27 menit. Awan konvektif bergerak dari arah Tenggara-Selatan disebabkan oleh faktor regional dengan kecepatan 1218 knot. Kelembapan udara 85-90\% berada di lapisan 840 mb-810 mb. Nilai VIL maksimum dari kasus hujan lebat adalah $5 \mathrm{~kg} / \mathrm{m}^{2}$ dan reflektivitas maksimum sebesar $58 \mathrm{dBz}$. Pertumbuhan awan konvektif yang menghasilkan hujan lebat 16 Februari 2016, terjadi selama 220 menit. Tahap cumulus terjadi selama 30 menit, tahap matang terjadi selama 150 menit, tahap dissipasi terjadi selama 40 menit. Awan konvektif bergerak dari arah Barat Laut yang disebabkan oleh faktor regional dengan kecepatan 5-10 knot. Kelembapan udara lebih dari 95\% berada di lapisan $400 \mathrm{mb}-200 \mathrm{mb}$.
\end{abstract}

Kata kunci : Waktu Hidup, Pergerakan, Awan Konvektif, Hujan Es, Hujan Lebat, Metode Digitasi

\begin{abstract}
Clouds as actors in the atmospheric dynamic, it is important to learn especially the convective cloud. Radar data is used to show the characteristic of convective clouds that producing hail and heavy rain with digitization method and life history method. Maximum VIL value of hail case studies in Bogor is $45 \mathrm{~kg} / \mathrm{m}^{2}$, maximum reflectivity is $65 \mathrm{dBz}$ reaches a height of $9 \mathrm{~km}$ at 08.12 UTC. Three Body Scatter Spike (TBSS) appear as a mark will occur hail process. The growth of convective clouds that producing hail on July 5 2016, in Bogor occurred for 140 minutes. The cumulus stage takes 33 minutes, the mature stage takes 80 minutes, and the dissipation stage takes 27 minutes. The convective clouds move from southeast-south is caused by regional factors, with speed 12-18 knots. Relative Humidity $(R H)$ 85-90\% is present in layers 840 mbar to 810 mbar. Maximum VIL value of heavy rain case studies is $5 \mathrm{~kg} / \mathrm{m}^{2}$ and maximum reflectivity is 58 $d B z$. The growth of convective clouds that producing heavy rain on February 16 2016, occurred for 220 minutes. The cumulus stage takes 30 minutes, the mature stage takes 150 minutes, and the dissipation stage takes 40 minutes. The convective clouds move from northwest is caused by regional factors, with speed 5-10 knots. Relative Humidity $(\mathrm{RH})$ is more than 95\% is present in layers 400 mbar to $200 \mathrm{mbar}$.
\end{abstract}

Keywords : Lifetime, Movement, Convective Cloud, Hail, Heavy Rain, Digitization Metho. 


\section{PENDAHULUAN}

Informasi waktu dan lokasi kejadian cuaca ekstrem didiseminasikan ke masyarakat sebagai upaya dalam merancang sistem peringatan dini cuaca. Awan sebagai aktor dalam dinamika atmosfer. Pola awan tampak dari planet berfluktuasi karena pembentukan, pemisahan, dan pergerakan karena massa udara sebagai fluida (Houze, 2014). Cuaca menjadi isu penting yang perlu dibahas karena mempengaruhi potensi bencana alam (Leyda and Negra, 2015).

Indonesia sebagai benua maritim di tropis menjadi tantangan terbesar bagi prakirawan. Meskipun Indonesia memiliki 2 musim, ketepatan prakiraan cuaca masih sulit. Faktor lokal yang bervariasi adalah penyebabnya. Kesulitan memprakirakan cuaca dapat diminimalisir dengan mengetahui karakteristik cuaca di wilayahnya (Katz and Murphy, 2005). Cuaca ekstrem mempengaruhi aktivitas manusia. Hujan lebat dan hujan es merupakan contoh dari cuaca ekstrem, jika telah melampaui batas normal. Karakteristiknya unik untuk dideskripsikan, terutama waktu hidup dan pergerakan. Sebuah upaya untuk merancang sistem peringatan dini cuaca adalah meneliti lebih lanjut tentang waktu hidup dan pergerakan awan konvektif. Lamanya waktu hidup awan konvektif berhubungan dengan lamanya waktu kejadian bencana, sementara pergerakan awan konvektif dihubungkan dengan diseminasi informasi area terdampak bencana. Kondisi konveksi atmosfer mampu membentuk awan konvektif (Tjasyono, 2006). Bencana alam bisa terjadi jika cuaca ekstrem menyebabkan bahaya dan kehilangan harta benda bahkan jiwa, jadi peringatan dini cuaca sangatlah penting untuk upaya mitigasi bencana (Leyda and Negra, 2015).

Salah satu alat yang dapat digunakan untuk mengidentifikasi waktu hidup dan pergerakan awan konvektif adalah radar cuaca. Radar menjadi contoh penginderaan jauh untuk mengukur objek di atmosfer bumi dengan sebuah jarak (Schowengerdt, 2006). Kemampuan radar melakukan scanning selama 5-10 menit memberikan pengolahan data dan interpretasi citra yang rinci. Proses dalam awan konvektif dapat dijelaskan dari fase tumbuh hingga meluruh.

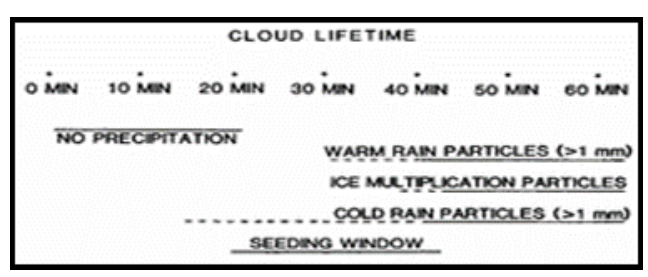

Gambar 1. Proses yang berpengaruh terhadap waktu hidup awan

Keunggulan Radar cuaca dibandingkan dengan pengamatan penginderaan jauh yang lainnya adalah kemampuan gelombang elektromagnetik yang dipancarkan radar cuaca dapat menembus ke dalam struktur awan hujan dan mengambil sampling dari kondisi droplet yang ada dalam struktur awan hujan dan badai sehingga mampu memberikan gambaran secara detail dan cepat tentang kondisi serta struktur dari awan badai (Wardoyo, 2015). Radar Doppler tipe C-band tersebar di beberapa tempat di kantor meteorologi Indonesia.

Pemanfaatan model cuaca numerik diharapkan dapat menginterpretasikan kondisi cuaca, khususnya untuk mengidentifikasi waktu hidup dan pergerakan awan konvektif. Era Interim Europian Center for Medium Range Weather Forecasting (ECMWF) dikembangkan untuk mensimulasikan proses dinamika atmosfer. Model ECMWF merupakan hasil dari perkembangan lebih dari 100 tahun studi meteorologi dinamis dan sinoptik dan lebih dari 50 tahun perkembangan studi Numerical Weather Prediction (NWP) (Persson dan Grazzini, 2007). Proses-proses kompleks di atmosfer ditinjau dalam model yang digambarkan pada sebuah grid.

Kajian ini menggunakan metode life history untuk menyelidiki fase pembentukan dari awan konvektif. Griffith, dkk (1978) menjelaskan metode life history telah banyak digunakan untuk kondisi konvektif, dengan menampilkan gambar dengan time step. Metode ini juga mempertimbangkan perubahan yang terjadi dalam pembentukan awan konvektif secara individu atau dalam cluster (Nagarajan, 2010). Berdasarkan latar belakang tersebut, penelitian tentang waktu hidup dan pergerakan awan konvektif perlu dikembangkan untuk membantu prakirawan 
dalam meningkatkan kualitas dan keakuratan prakiraan cuaca.

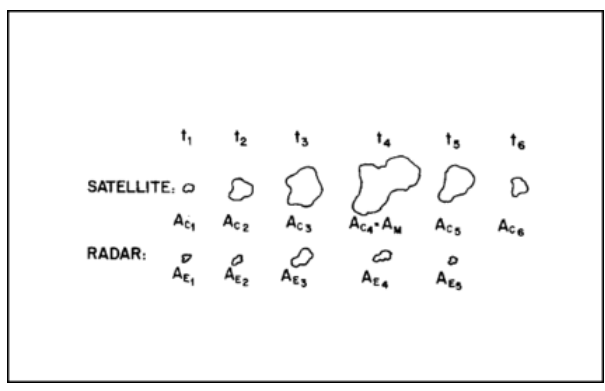

Gambar 2. Metode life history

Wilson dan Reum (1988) menyatakan bahwa hujan es pada radar ditandai dengan adanya Three-Body Scatter Spike (TBSS) dengan nilai reflektivitas $\leq 20 \mathrm{dBZ}$ pada ketinggian 10-20 km. Menurut Amburn dan Wolf (1997), nilai VIL sebagai indikator untuk terjadinya hujan es $>25 \mathrm{~kg} / \mathrm{m}^{2}$. Waldvogel, dkk (1979) juga menjelaskan indikator terjadinya hujan es dengan nilai reflektivitas maksimum mencapai $\geq 45 \mathrm{dBz}$ dengan ketinggiannya $\geq 4$ km. Gamache dan Houze (1981) mengungkapkan nilai reflektivitas saat fase konvektif aktif adalah lebih dari $38 \mathrm{dBz}$.

\section{DATA DAN METODE}

Penelitian menggunakan data radar dan model ECMWF untuk mendeskripsikan karakteristik hujan es. Salah satu produk radar, CMAX, didigitasi dengan software pengolah peta untuk mendeliniasi awan dan posisi inti sel awan konvektif.

Posisi inti sel diamati dalam mempertimbangkan pergerakan awan. Inti sel adalah objek dengan reflektivitas paling maksimum.

Data radar menggunakan raw data radar cuaca format ".vol". Radar cuaca Tangerang berlokasi pada koordinat $6.1669{ }^{\circ} \mathrm{LS}$ dan $106.6502{ }^{\circ}$ BT. Metode operasional pada waktu studi kasus menggunakan Volume Coverage Pattern (VCP) 21 yang memiliki 11 elevasi, dari 0.50 sampai 19.50. Pulse Repetition Frequency (PRF) digunakan nilai $600-800 \mathrm{~Hz}$ dan jangkauan area data digunakan hingga radius $3-150 \mathrm{~km}$.

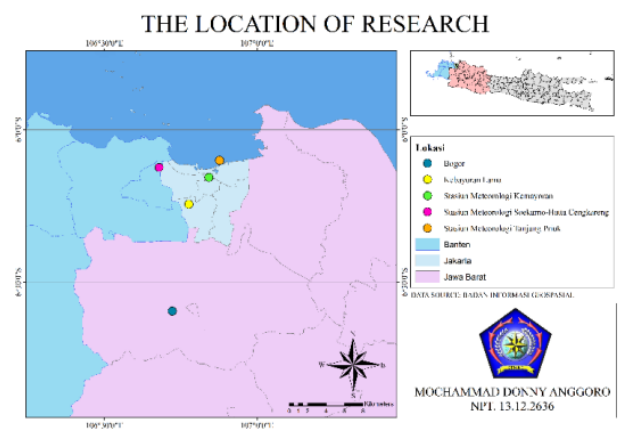

Gambar 3. Lokasi penelitian.

Produk Column Maximum (CMAX), produk Rainhistograph, dan produk Severe Weather Warning Index (SWWI) berdasarkan Volume Integrated Liquid (VIL) yang digunakan untuk membagi waktu tahap cumulus hingga tahap dissipasi. Produk tersebut dikonfigurasi berdasarkan pengaturannya masing-masing. Produk CMAX memperoleh nilai reflektivitas maksimum di tiap scanning. Produk Rainhistograph mengkonversi nilai reflektivitas dari produk CMAX dengan algoritma Marshall-Palmer. Produk VIL menunjukkan kolom udara dengan banyak uap air, jadi dapat dideteksi seberapa besar potensi awan konvektif terbentuk. Produk CMAX menjadi bahan untuk dilakukan metode digitasi dari lapisan terendah $0.3 \mathrm{~km}$ dan lapisan teratas $30 \mathrm{~km}$. Produk Rainhistograph diatur selama 24 jam.

Model ECMWF digunakan untuk melihat factor regional yang mempengaruhi pertumbuhan awan. Data ECMWF dengan resolusi $0.125^{\circ} \times 0.125^{\circ}$, area $10{ }^{\circ} \mathrm{LU}$ $15{ }^{\circ} \mathrm{LS}$ and $90{ }^{\circ} \mathrm{BT}-145{ }^{\circ} \mathrm{BT}$, yang termasuk:

a. Streamline lapisan bawah $(850 \mathrm{mb})$, lapisan menengah $(500 \mathrm{mb})$, dan lapisan atas (200 $\mathrm{mb})$.

b. Lapisan kelembapan udara $850 \mathrm{mb}$ hingga $200 \mathrm{mb}$.

Parameter-parameter dianalisis menggunakan streamline dan kelembapan udara. Model ECMWF diekstrak setiap 6 jam (07 WIB, 13 WIB, 19 WIB, dan 01 WIB), jadi studi kasus yang diambil pada model waktu sebelum dan setelah kejadian.

Metode life history menggunakan gambar dan time step. Software pengolah peta mengawali tahap georeferencing, yang mendefinisikan beberapa titik dengan gambar (data digital) untuk mengetahui koordinat 
lokasi. Peneliti menggunakan 4 titik berbentuk persegi panjang. Titik pertama adalah pusat radar Tangerang (106.6502 ${ }^{\circ} \mathrm{BT}$, $6.1502 \quad{ }^{\circ}$ LS). Titik kedua adalah menggunakan lintang pusat radar dan bujur pusat kota Bekasi (106.9215729 $\left.{ }^{\circ} \mathrm{BT}\right)$. Titik ketiga dan keempat diperbolehkan mengambil titik acak tetapi tetap membentuk persegi panjang.

\section{HASIL DAN PEMBAHASAN}

Metode digitasi menggunakan banyak gambar untuk menginformasikan pertumbuhan awan konvektif. Pembagian tahap pertumbuhan awan konvektif, jika reflektivitas maksimum lebih dari $38 \mathrm{dBz}$ berarti sel tersebut telah memasuki tahp matang. Setelah semua didigitasi, metode life history berguna untuk analisis data dengan menghubungkan model dan radar.

a. Kasus Hujan Es 5 Juli 2016 di Bogor

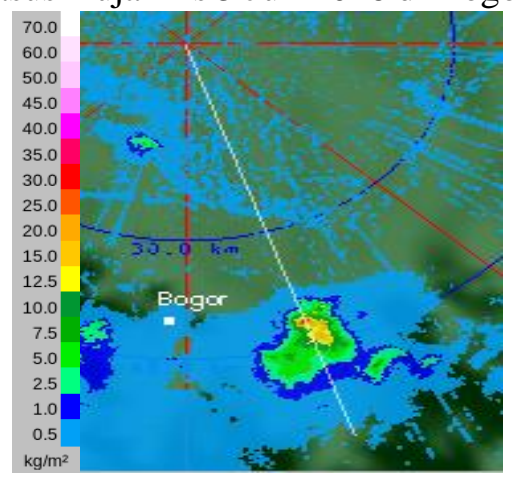

Gambar 4. Produk VIL

Gambar 4 menunjukkan produk VIL pada jam 15.12 WIB. Karakteristik hujan es di Bogor sesuai dengan penelitian Amburn dan Wolf (1997), dimana terdapat nilai VIL maksimum lebih dari lebih dari $25 \mathrm{~kg} / \mathrm{m}^{2}$. Gambar 5 terlihat nilai reflektivitas maksimum sebesar $65 \mathrm{dBz}$ mencapai ketinggian $9 \mathrm{~km}$. Terlihat pola TBSS, dimana pola mirip reflektivitas maksimum.

Metode digitasi digunakan untuk menggambarkan pertumbuhan awan konvektif, dimulai dari tahap cumulus, tahap matang, dan tahap dissipasi. Pengolahan data radar dengan metode ini menggunakan skala 1:100,000. Penggunaan skala ini bertujuan agar gambar terlihat secara rinci. Tahap cumulus teridentifikasi dari jam 13.59 WIB sampai 14.32 WIB.
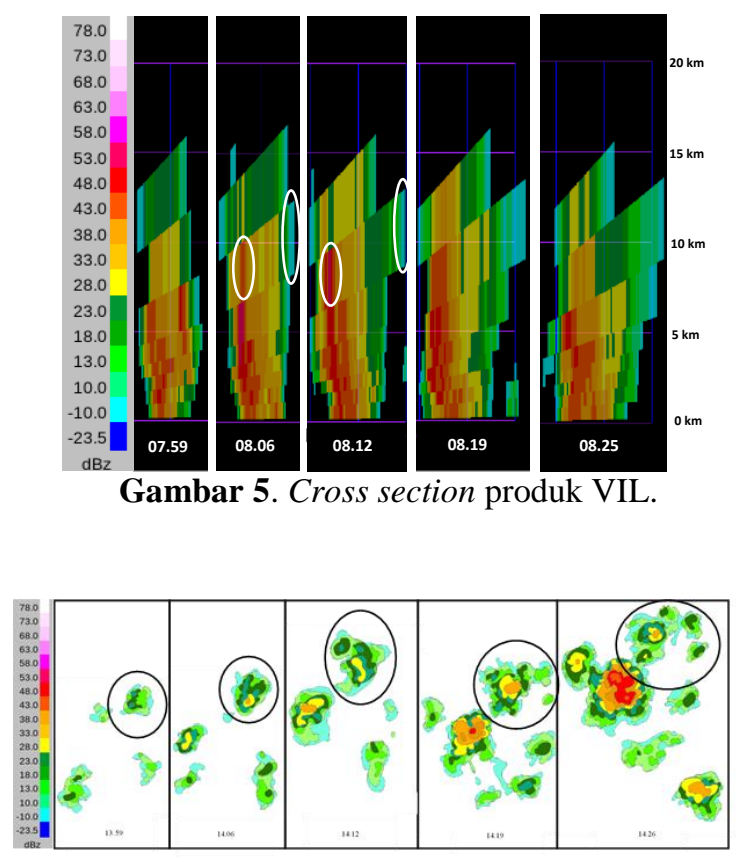

Gambar 6. Tahap cumulus awan konvektif.

Tahap matang menggunakan skala 1:50,000. Skala pada tahap cumulus lebih besar daripada skala pada tahap matang bertujuan agar gambar yang dihasilkan lebih besar dan dapat terlihat secara rinci. Tahap matang teridentifikasi dari jam 14.32 WIB sampai 15.52 WIB. Waktu ini dipilih karena bentuk awan mulai dalam kondisi stabil dan ukurannya konstan pada system perawanan. Nilai reflektivitas mulai dari $38 \mathrm{dBz}$ sampai $65 \mathrm{dBz}$.

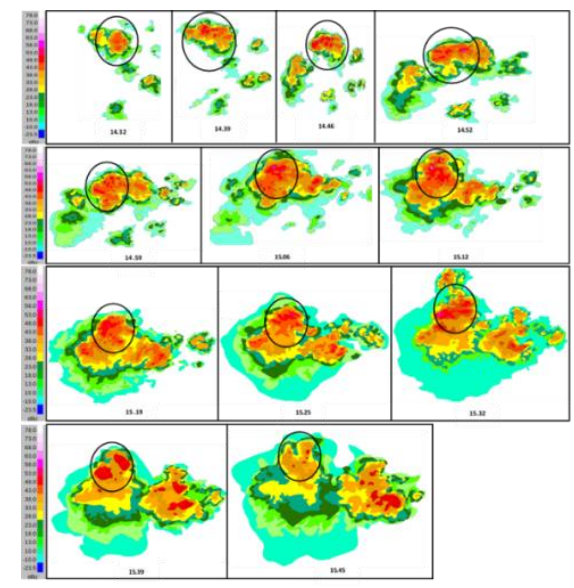

Gambar 7. Tahap matang awan konvektif. 


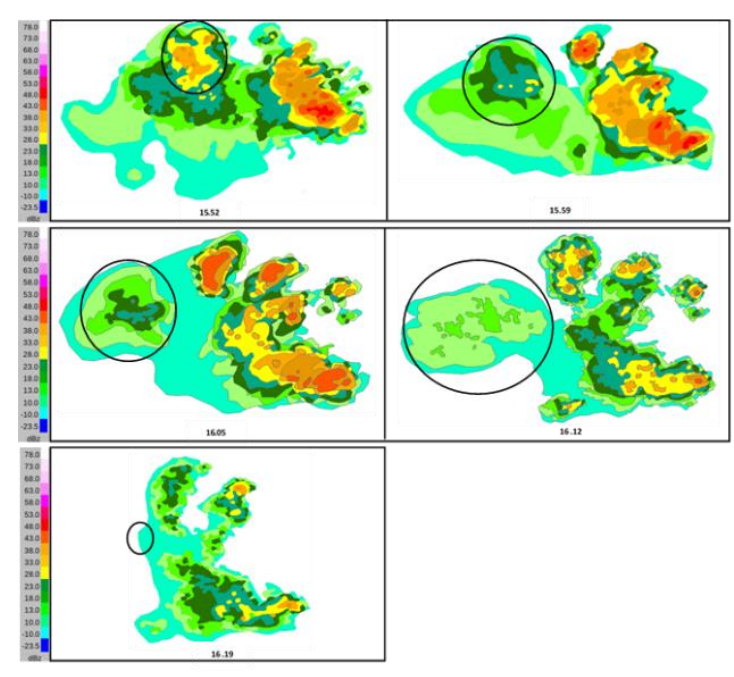

Gambar 8. Tahap dissipasi awan konvektif.

Tahap dissipasi menggunakan skala 1:50,000. Tahap dissipasi diilustrasikan ketika nilai reflektivitas maksimum menurun dan di bawah $38 \mathrm{dBz}$, dari jam 15.52 WIB sampai 16.19 WIB. Waktu ini dipilih karena ukuran sel menjadi lebih kecil dan sistem konvektif mulai pecah. Reflektivitas maksimum menurun dari $38 \mathrm{dBz}$ pada jam 15.52 WIB sampai $20 \mathrm{dBz}$ pada jam 16.19 WIB, hingga pada akhirnya sel punah dan tidak terlihat lagi pada citra radar. Sel terpilih merupakan sel yang memiliki warna reflektivitas berurutan.

Pertumbuhan awan konvektif penghasil hujan es 5 Juli 2016 di Bogor berlangsung selama 140 menit. Tahap cumulus terjadi selama 33 menit, tahap matang terjadi selama 79 menit, dan tahap dissipasi terjadi selama 34 menit.

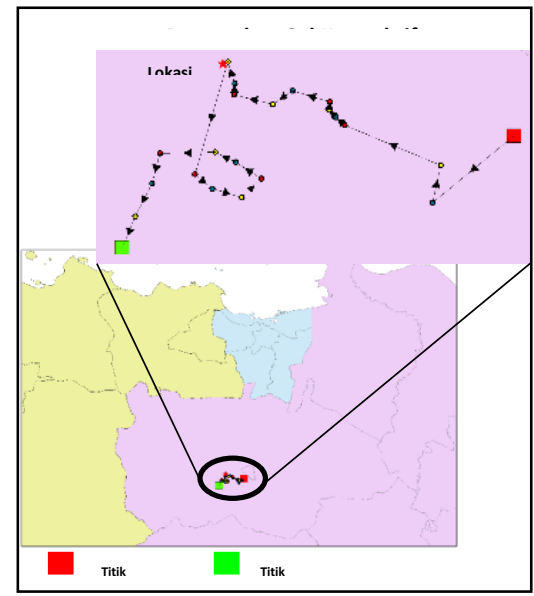

Gambar 9. Pergerakan awan konvektif

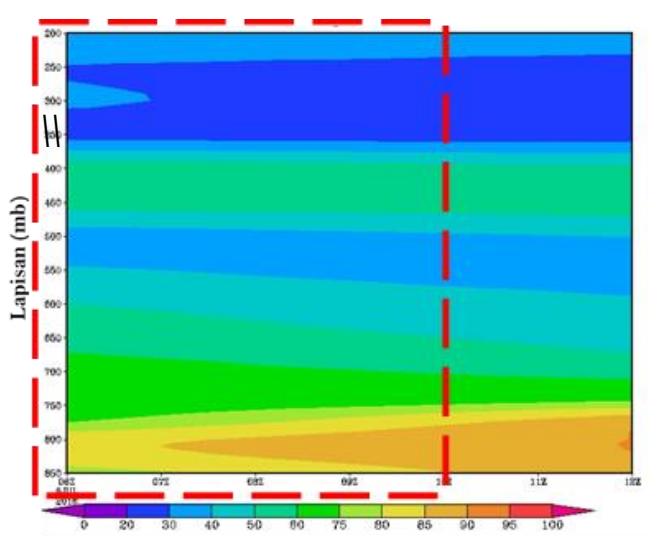

Gambar 10. Kelembapan udara 5 Juli 2016.

Gambar 9 menunjukkan pergerakan awan konvektif dari jam 13.59 WIB hingga 16.19 WIB. Jam 13.59 WIB sampai 14.06 WIB awan bergerak ke arah Barat Daya. Jam 14.06 WIB sampai 15.12 WIB, awan bergerak ke arah Barat Laut. Jam 15.12 WIB sampai 16.19 WIB, awan bergerak kembali ke arah Barat Daya dengan adanya perputaran berlawanan arah jarum jam yang diindikasikan perubahan angin dominan di tiap lapisan. Tanda bintang merah adalah lokasi terjadinya hujan es. Kotak berwarna menunjukkan titik awal pergerakan, sedangkan kotak berwarna hijau menunjukkan titik akhir pergerakan.

Gambar 10 menunjukkan pada jam 13.00 WIB sampai jam 17.00 WIB (ditandai dengan garis merah putus-putus), lapisan bawah mengandung udara yang cukup basah pada sekitar jam 15.12 WIB. RH 85-90 \% terdapat di lapisan $840 \mathrm{mb}$ hingga $810 \mathrm{mb}$. Kondisi ini mendukung untuk pertumbuhan awan.

b. Kasus Hujan Lebat 16 Februari 2016

Hujan lebat pada tanggal 16 Februari 2016 didasarkan pada data hujan di Stasiun Meteorologi Kemayoran.

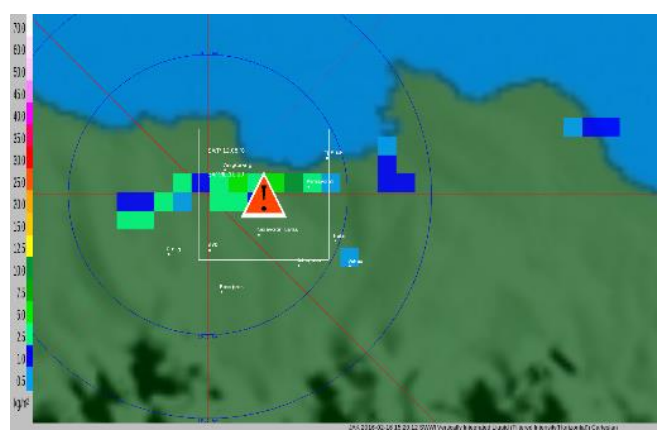

Gambar 11. Produk SWWI jam 22.20 WIB. 
Gambar 11 menunjukkan nilai VIL maksimum terjadi pada jam 22.20 WIB. Citra produk SWWI tersebut menunjukkan nilai VIL maksimum sebesar $10 \mathrm{~kg} / \mathrm{m}^{2}$. Nilai VIL ini terbilang rendah, sebagai karakteristik kasus hujan lebat. Tanda seru pada gambar menandakan potensi terjadinya cuaca buruk. Pembagian waktu tiap fase pertumbuhan didasarkan pada nilai reflektivitas maksimum hasil digitasi produk CMAX. Semua digitasi menggunakan skala 1:50.000.

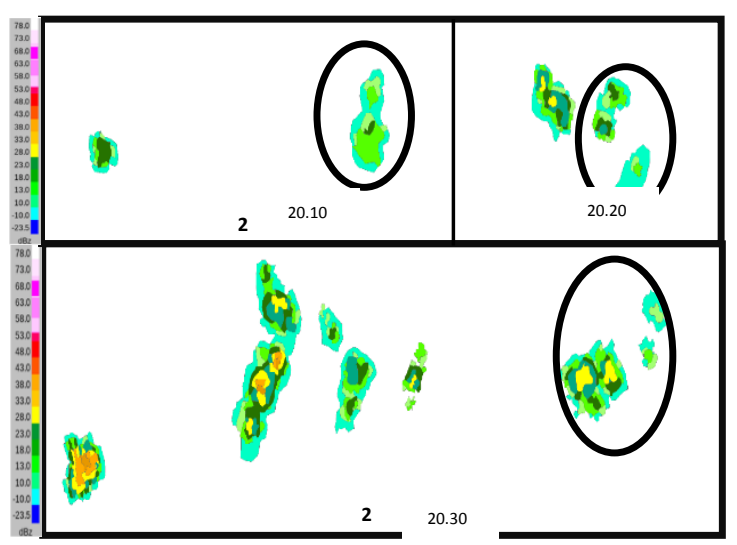

Gambar 12. Tahap cumulus awan konvektif

Tahap cumulus diidentifikasi mulai dari jam 20.10 WIB hingga jam 20.40 WIB, yaitu selama 30 menit. Gambar 12 terlihat sel-sel konvektif yang tersebar mulai terorganisir menuju nilai reflektivitas $38 \mathrm{dBz}$. Awal mula munculnya awan pada jam 20.10 WIB memiliki reflektivitas maksimum $18 \mathrm{dBz}$, naik menjadi $23 \mathrm{dBz}$ pada jam 20.20 WIB. Luasan sel awan semakin melebar dan reflektivitas maksimum mengalami peningkatan menjadi $28 \mathrm{dBz}$ pada jam 20.30 WIB.Tahap matang diidentifikasi mulai dari jam 20.40 WIB hingga jam 23.10 WIB, yaitu selama 150 menit. Waktu ini dipilih karena bentuk awan mulai stabil dan ukuran awan yang konstan.

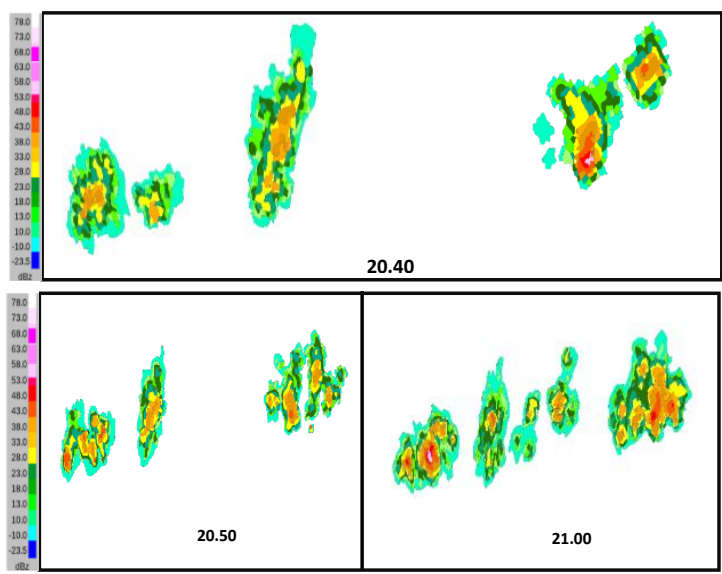

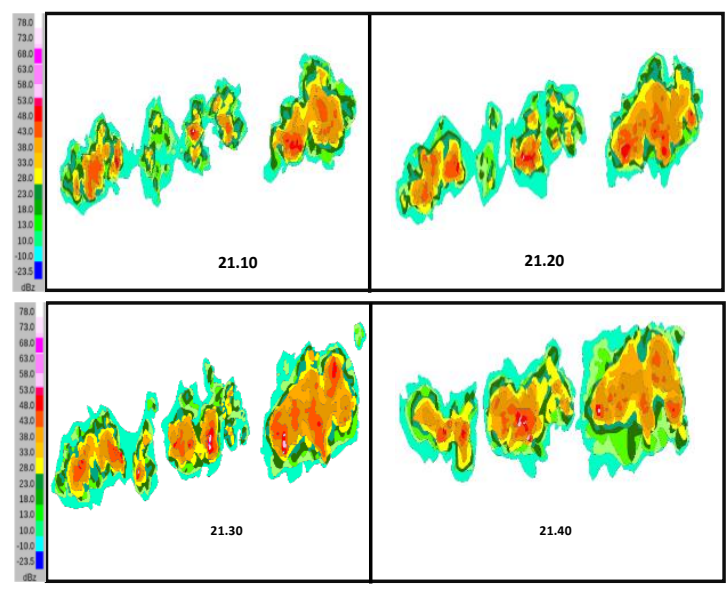

Gambar 13. Awal tahap matang awan konvektif

Gambar 13 menunjukkan pemisahan awan konvektif dari jam 20.40 WIB sampai 20.50 WIB. Intensitas dari reflektivitas inti sel mengalami penurunan. Sel awan pada kasus ini tergolong dalam multicell, ditandai dengan pemisahan dan indikasi penggabungan kembali pada jam 21.00 WIB.

Gambar 14 juga menunjukkan proses penggabungan awan konvektif menjadi pumpunan. Reflektivitas maksimum paling besar nilainya terdapat pada jam 22.40 WIB sebesar $53 \mathrm{dBz}$. Hal ini berarti bahwa pada jam tersebut menjadi penanda potensi turunnya hujan lebat sangat besar. Luasan reflektivitas maksimum menjadi besar dan paling luas terjadi pada jam 23.00 WIB.

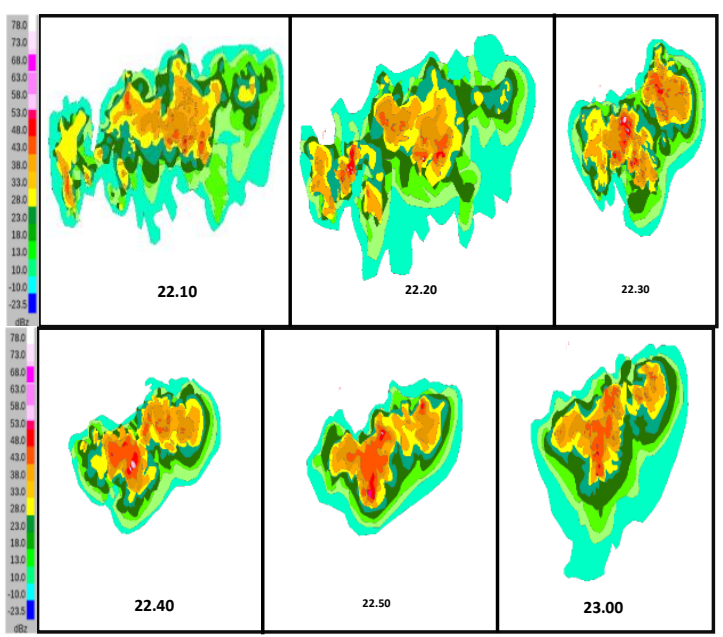

Gambar 14. Tahap matang awan konvektif. 


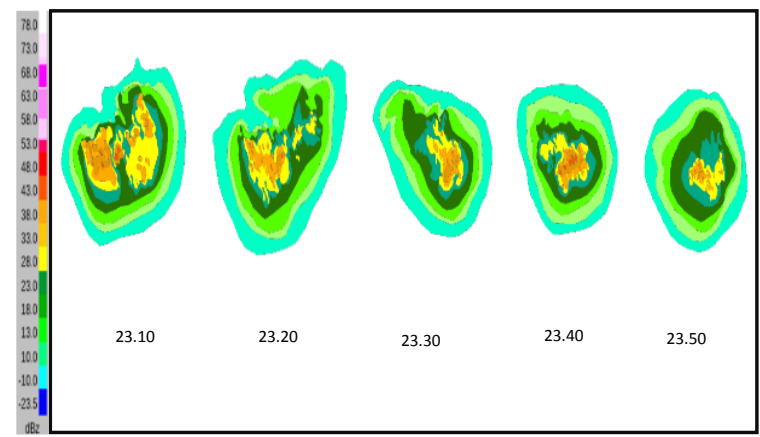

Gambar 15. Tahap dissipasi awan konvektif.

Fase dissipasi terjadi dari jam 23.10 WIB sampai jam 23.50 WIB, yaitu selama 40 menit. Luasan awan terlihat semakin mengecil dan intensitas reflektivitas maksimum stagnan. Nilai reflektivitas maksimum lebih kecil dari $38 \mathrm{dBz}$.

Pertumbuhan awan konvektif penghasil hujan lebat 16 Februari 2016 terjadi selama 220 menit. Tahap cumulus membutuhkan waktu 30 menit, tahap matang membutuhkan waktu 150 menit, dan tahap dissipasi membutuhkan waktu 40 menit. Pergerakan awan konvektif dari jam 20.10 WIB sampai jam 23.50 WIB ke arah Tenggara-Selatan.

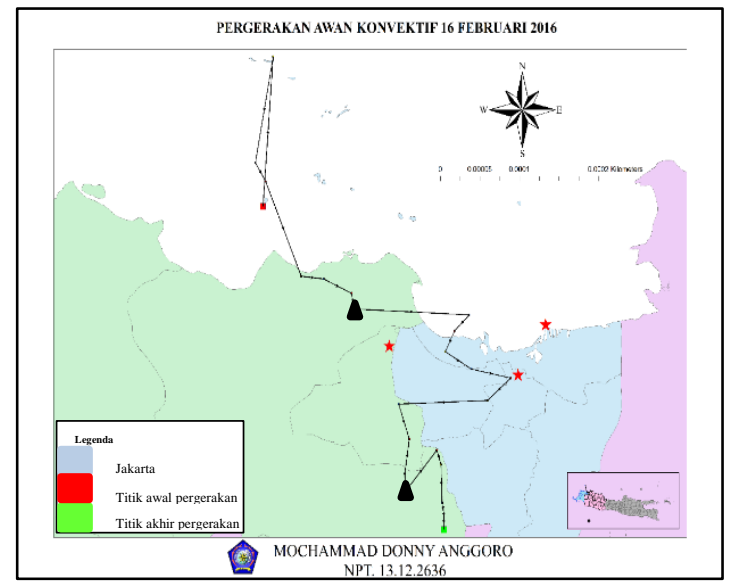

Gambar 16. Pergerakan awan konvektif

Kelembapan udara dari jam 20.10 WIB sampai 23.50 WIB relatif lebih basah di lapisan atas dibandingkan lapisan bawah. Secara vertikal umumnya basah, dimana lapisan bawah bernilai $75 \%$ - $90 \%$ dan $\mathrm{RH}>100 \%$ di lapisan 300-250 mb.

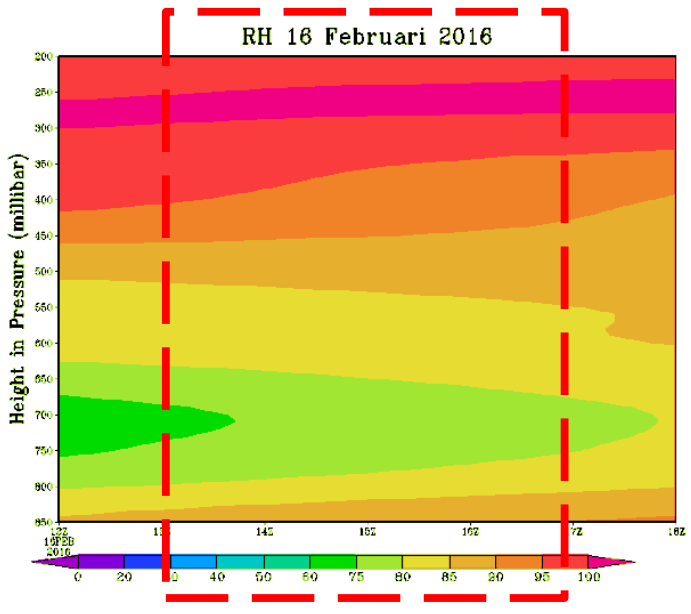

Gambar 17. Kelembapan udara 16 Februari 2016.

\section{KESIMPULAN}

Berdasarkan tujuan penelitian dan hasil pembahasan didapatkan kesimpulan bahwa waktu hidup awan konvektif pada kasus hujan es di Bogor pada 5 Juli 2016 adalah 140 menit dengan tahap cumulus 33 menit, tahap matang 80 menit, dan tahap dissipasi 27 menit. Pergerakan awan konvektif penghasil hujan es ke arah Tenggara-Barat Daya. Waktu hidup awan konvektif pada kasus hujan lebat di wilayah Jabodetabek adalah 220 menit dengan tahap cumulus 30 menit, tahap matang 150 menit, dan tahap dissipasi 40 menit. Pergerakan awan konvektif penghasil hujan lebat ke arah Tenggara-Barat Daya.

Perlu penambahan studi kasus (musim transisi) yang dianalisis untuk memperkuat penelitian ini. Parameter yang menggambarkan kondisi atmosfer juga ditambah, untuk menjadi pedoman bagaimana awan konvektif terbentuk. Diharapkan juga penelitian selanjutnya mampu menghitung waktu hidup sejak awan konvektif benarbenar mulai tumbuh.

\section{DAFTAR PUSTAKA}

Amburn, S.A. dan Wolf, P.L. 1997. VIL density as a hail indicator, Weather Forecasting, 473-478.

Gamache, J.F. dan Houze, R.A. 1981. Mesoscale Air Motions Associated with a Tropical Squall Line, Department of Atmospheric Sciences, University of Washington, Seattle. 
Griffith, C.G., Woodley, W.E., dan Grube, P.G. 1978. Rain estimation from geosynchronous satellite imagery-Visible and Infrared Study, Mon, Weath, 106.

Houze, R. 2014. Cloud Dynamics (Second Edition), Academic Press, 2014.

Leyda, J. dan Negra, D. 2015. Extreme Weather and Global Media, Routledge, New York.

Nagarajan, R. 2010. Drought Assessment, Springer Science \& Business Media.

Persson, A. dan Grazzini, F. 2007. User Guide to ECMWF Forecast Products, ECMWF, United Kingdom.
Schowengerdt, R. 2006. Remote Sensing: Models and Methods for Image Processing, Academic Press.

Tjasyono, B. 2006. Meteorologi Indonesia 2 (Awan \& Hujan Monsun), BMKG, Jakarta.

Waldvogel, A., Federer, B., dan Grimm, P. 1979. Criteria for the detection of hail cells, J. Appl. Meteor, 18.

Wardoyo, E. 2015. Radar Meteorologi, BMKG, Jakarta.

Wilson, J.W., dan Reum, D. 1988. The flare echo: Reflectivity and velocity signature. J. Atmos. Oceanic Technol, 197-205. 